\title{
Heavy metals pollution in the soils of suburban areas in big cities: a case study
}

\author{
H. Taghipour $\cdot$ M. Mosaferi $\cdot$ F. Armanfar • \\ S. J. Gaemmagami
}

Received: 9 July 2011/Revised: 4 May 2012/ Accepted: 20 June 2012/Published online: 15 January 2013

(C) CEERS, IAU 2013

\begin{abstract}
Soil pollution in agricultural areas surrounding big cities is a major environmental problem. Tabriz is the largest city in the northwest of Iran and the fourth largest city in the country. Soil samples were taken from 46 sites in the suburbs of the Tabriz city, and separate samples were taken from control site and analyzed. The results indicated that the mean $\mathrm{pH}$ value of the soil samples was 9.29 , while the mean EC value was $354.33 \mu \mathrm{s} / \mathrm{cm}$ and the amount of TOC and TOM was 0.99 and $1.7 \%$, respectively. The mean concentrations of $\mathrm{Cd}, \mathrm{Pb}, \mathrm{Cu}, \mathrm{Cr}, \mathrm{Ni}$, and $\mathrm{Zn}$ in the soil were determined to be $1.61,10.56,101.25,87.40$, 38.73 , and $98.27 \mathrm{mg} / \mathrm{kg}$, respectively (dry weight). The concentrations of heavy metals $(\mathrm{Cd}, \mathrm{Pb}, \mathrm{Cu}, \mathrm{Cr}$, and $\mathrm{Zn})$, with the exception of $\mathrm{Ni}$, were higher than the concentrations of the same heavy metals at the control site. Despite these elevated concentrations, the concentrations of heavy metals were lower than the toxicity threshold limit of agricultural soils. The values of the pollution index
\end{abstract}

H. Taghipour

Department of Environmental Health Engineering, Tabriz Health Services Management Research Center and Nutrition Research Center, Tabriz University of Medical Sciences, Tabriz, Iran

M. Mosaferi

Tabriz Health Services Management Research Center, Department of Environmental Health Engineering, Tabriz University of Medical Sciences, Tabriz, Iran

F. Armanfar $(\bowtie)$

Regional Water Organization of East Azerbaijan Province, Tabriz, Iran

e-mail: f_armanfar@yahoo.com

S. J. Gaemmagami

Nutrition Research Center and Department of Nutrition, Biochemistry and Diet Therapy, Tabriz University of Medical Sciences, Tabriz, Iran revealed that the metal pollution level was $\mathrm{Pb}>\mathrm{Cr}>$ $\mathrm{Cu}>\mathrm{Zn}>\mathrm{Cd}>\mathrm{Ni}$, and the mean value of the integrated pollution index was determined to be 1.81 , indicating moderate pollution. Nevertheless, there were some sites that were severely polluted by $\mathrm{Cr}$ (maximum values of $1,364 \mathrm{mg} / \mathrm{kg}$ ). It was concluded that city probably has affected the surrounding agricultural area. Application of wastewater (municipal and industrial) as irrigation water, using of sludge as soil fertilizer, and atmospheric perceptions have been considered as main reasons of increased heavy metals concentrations found in the studied area.

Keywords Agricultural area - Assessment . Heavy metals · Soil

\section{Introduction}

Soil pollution in agricultural areas surrounding big cities is a major environmental problem. Heavy metals pollution in the soil has become a serious issue due to a number of human activities, such as those related to the mining, mineral, smelting, and tannery industries (Moller et al. 2005; Kasassi et al. 2008). Heavy metals contribute to environmental pollution because of their unique properties; heavy metals are non-biodegradable, non-thermo-degradable, and generally do not leach from the topsoil and have the potential to accumulate in the different organs (such as the kidneys, bones, and liver) leading to unwanted side effects (Radwan and Salama 2006; Singh et al. 2010). Each heavy metal shows specific signs of its toxicity. For instance $\mathrm{Pb}, \mathrm{As}, \mathrm{Hg}$, $\mathrm{Zn}, \mathrm{Cu}$, and $\mathrm{Al}$ poisoning have been implicated with gastrointestinal (GI) disorders, diarrhoea, stomatitis, tremor, hemoglobinuria causing a rust-red color to stool, ataxia, paralysis, vomiting and convulsion, depression, and 
pneumonia. Some effects of heavy metals can be toxic (acute, chronic or sub-chronic), neurotoxic, or even carcinogenic, mutagenic or teratogenic (Singh et al. 2010; European Union 2002). Unlike other pollutants such as petroleum, hydrocarbons, and litter that visibly accumulate on soils, heavy metals can go unnoticed while accumulating at concentrations that are toxic to plants and animals. Heavy metals can continue to contaminate the surrounding environment for hundreds or thousands of years, even after they are no longer being added to the soil (Mapanda et al. 2005). Several researchers have clearly demonstrated that human activities are a major cause of metal contamination in the ecosystem (Kasassi et al. 2008).

More than half of the world's population lives in urban areas. Substantial rural-urban migration in developing countries is causing a rapid expansion of the peri-urban interface, where domestic and industrial modifications of the environment interact strongly with agricultural production (Huang et al. 2006). Therefore there is growing concern regarding the contamination of water, soil, and agricultural produce throughout rapidly urbanizing areas in Asia (Huang et al. 2006).

In the meantime, there are some risks in some Iranian cities, especially in large cities, for a number of reasons. First, a large urban population generate a large amount of waste, (such as sludge from industries and sometimes from municipal wastewater treatment plants) some of which is applied to surrounding lands. Second, the water shortage in these cities exacerbates heavy metals contamination. Because the society municipal or industrial wastewaters are discharged with little or no treatment in natural water bodies, which can become highly polluted, farmers in urban and peri-urban areas who are in need of water for irrigation have often little or no choice than using wastewater or polluted water as irrigation water (Qadir et al. 2010). On the other hand, intensive peri-urban vegetable and crop production leads to use of large quantities of organic wastes, fertilizers, pesticides, and likely contaminated irrigation water (which became polluted by municipal and industrial wastewater). In addition, many industries (such as battery production, metal products, dye and pigment, power plants, electroplating industries metal smelting \& Cable coating industries, etc.) are being constructed in urban areas, posing a high risk of industrial pollution of water and air that may have direct impacts on public health, as well as indirect effects via vegetable production and soil pollution (Kaushik et al. 2009).

The selected area for the present study is Tabriz, Iran. Tabriz is the largest city in the northwest of Iran and the fourth largest city in the country, with a population of $1,523,085$ people (2006) and an area of $45,481 \mathrm{~km}^{2}$. The city is located on the north of Sahand volcanic cone and south of the Eynali Mountain at an altitude of $1,340 \mathrm{~m}$ above sea level, latitude of $38.07^{\circ} \mathrm{N}$, and a longitude of $46.28^{\circ} \mathrm{E}$. The dominant winds in the Tabriz are from east and northeast. The average raining amount is $289 \mathrm{~mm} /$ year (Koshhal and Gavidel 2009). The region has undergone heavy urbanization and development in recent decades. The largest industrial areas, such as areas focused on tractor manufacturing, car industry, industrial machines, tannery, chemical, petrochemical, refinery, cement, food, and agricultural farms, are located in the suburbs, and particularly in the western suburbs of the city. On the other hand, urban populations in the city and suburbs are increasing, and residents are seeking better living standards as those in other economically developing countries. Consequently, larger amounts of freshwater are diverted to domestic, commercial, and industrial sectors, which generate greater volumes of wastewater. Commonly, surface polluted water from the city and wastewaters from some suburban industrial areas that have received little or no treatment are being discharged into natural water bodies, which can become highly polluted. Farmers in urban and periurban areas of cities who are in need of water for irrigation have often no other choice (with the exception of farms with well water) but to use wastewater and surface polluted water. Of course, due to the strict control and mentoring by health and agricultural officials, as well as an increasing awareness of the pollution of the water and soil, the use of wastewater and surface polluted water in the irrigation of farms in the suburbs of cities has recently been limited, especially for vegetable and other commonly consumed crops. However, there is a concern about the soil pollution in areas with heavy metals, especially in the western suburb of city. This concern likely comes from the past applications or present stealth uses of wastewater for the irrigation of farmland, and other sources of heavy metals pollution, such as the use of large quantities of organic wastes, fertilizers, pesticides, and atmospheric perceptions. On the other hand, there are no reported research studies on the soil heavy metals conditions in this area. The main objective of this study was to characterize heavy metals levels of the soil (lead, cadmium, copper, zinc, nickel, and chromium) in western industrial and agricultural areas of Tabriz.

\section{Materials and methods}

The sites (on the Tabriz suburban agricultural areas) used for soil sampling are shown in Fig. 1 (it should be explained that, all of the sites are not visible in the figure; due to limited size of figure some numbered points are hidden behind the other points). A total of 46 samples were taken from the western suburb of Tabriz city. In addition, control samples were taken from land near to the study area which has never been used as farmland (No 47). As shown in Fig. 1, the sites were selected in such a way to cover all the agricultural areas of the city suburbs. Composite samples were made up of three sub-samples from each site. A 


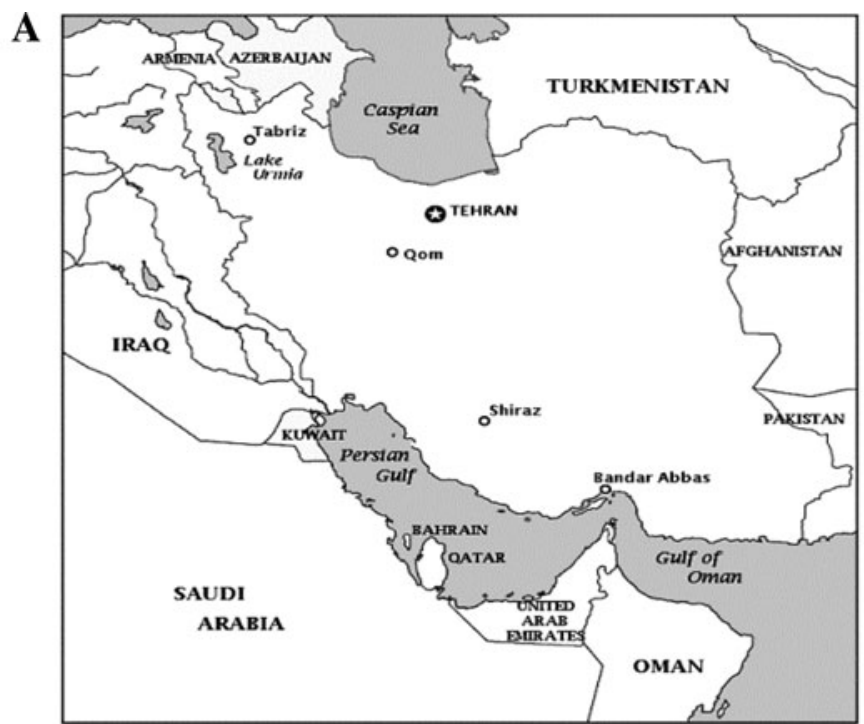

B

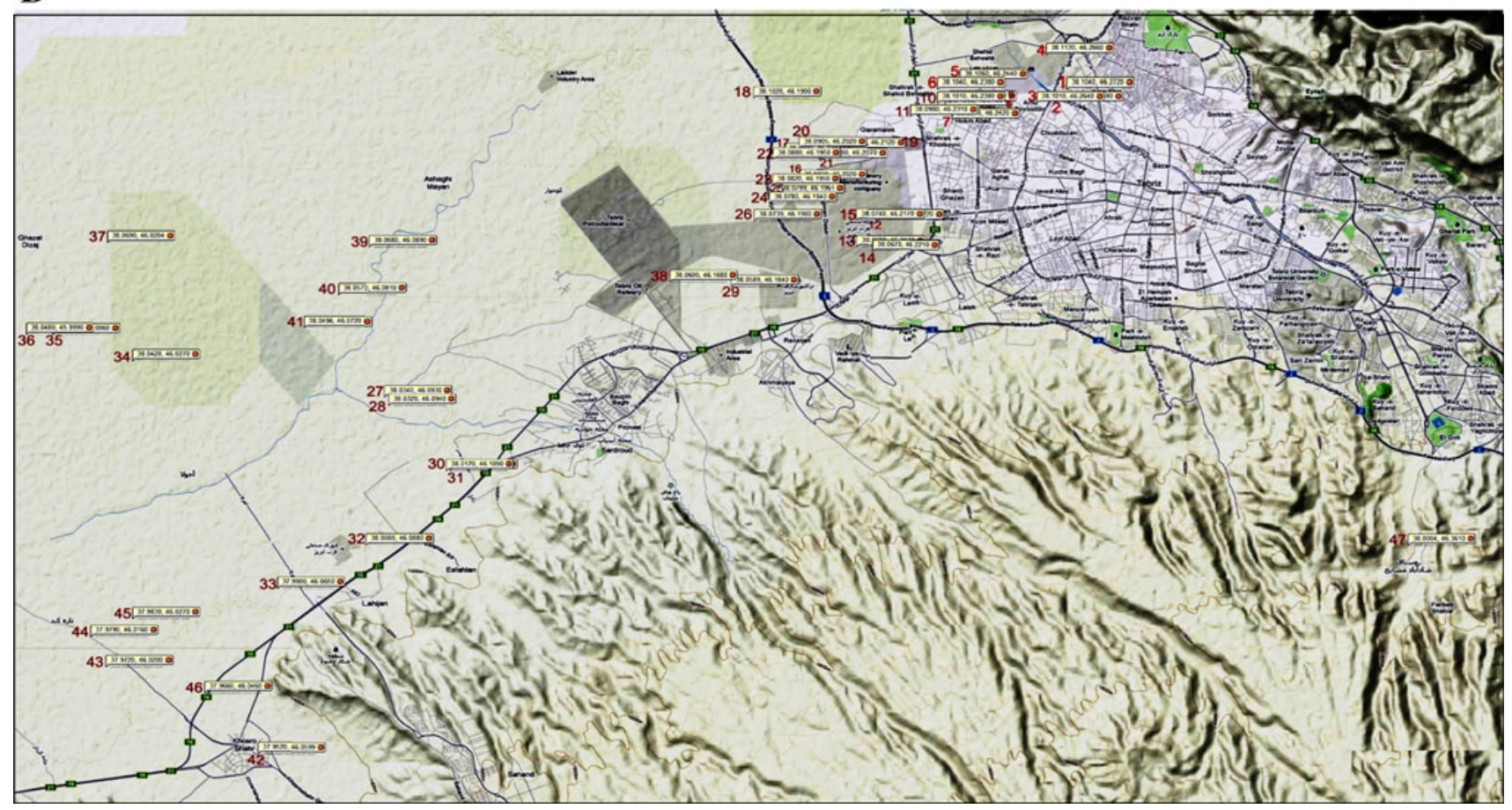

Fig. 1 Location of the study area (Tabriz) (a) and soil sampling locations in the suburbs of city (b)

monolith of approximately $10,10,15 \mathrm{~cm}$ (length, breadth, and depth values respectively) was dug for the collection of soil. A stainless steel trowel was used to collect samples that were stored in plastic bags while being transferred to the laboratory. Soil samples were air-dried for $72 \mathrm{~h}$, crushed, passed through a 2-mm-mesh sieve, and stored at ambient temperature before soil properties and concentrations of heavy metals were analyzed (Sharama et al. 2007). The general soil properties of studied area indicated clay (32.76\% SD \pm 4.57$)$, sand (33.68\% SD \pm 4.57$)$, and silt (33.56\%) (Asgharszadeh et al. 2001).
All the containers used in the analysis were cleaned with a detergent solution, rinsed with tap water, soaked in acid $(2+1 \mathrm{HCl})$, and then rinsed with metal-free water. Metals in the soil that were extractable by aqua regia were measured. From each dried sample, portions of approximately $20 \mathrm{~g}$ were ground until fine particles were obtained, and $1.5-\mathrm{g}$ samples were then weighed into a flask, In a hood, $\mathrm{HNO}_{3}$ (4 $\mathrm{ml}$ ) and concentrated $\mathrm{HCl}$ (12 $\mathrm{ml}$, aqua regia) were added, covered with a watch glass, and allowed to stand overnight (for at least for $12 \mathrm{~h}$ ). The next day, the mixture was heated progressively and boiled under reflux for $2 \mathrm{~h}$, after which the 
digestion flask was cooled. The cooling column was rinsed with $15 \mathrm{ml}$ of deionized water, and the rinse water was recovered in the digestion flask. After cooling and rinsing, the ingests were passed through a pre-washed filter (Whatman No. 540), and the digestion flasks were rinsed three times; the washings were passed through the filter, and the filtrates were used to make a volume of up to $100 \mathrm{ml}$ using ultra pure $2 \mathrm{M} \mathrm{HNO}_{3}$. The prepared samples were refrigerated in acid-washed polyethylene bottles at $4{ }^{\circ} \mathrm{C}$ before the final analysis of the heavy metals concentrations (APHA 2006; Alexander et al. 2006; Mapanda et al. 2005). The soil $\mathrm{pH}$ was measured in a suspension of 1:5 soil to water using a glass electrode (Sharama et al. 2007). In the same suspension, the conductivity was measured using a conductivity meter and the organic carbon was determined using Walkley and Black's method (Page et al. 1982).

The concentrations of heavy metals in digested soil samples were determined with an atomic absorption spectrophotometer fitted with a specific lamp of $\mathrm{Pb}, \mathrm{Cd}, \mathrm{Cu}, \mathrm{Zn}$, $\mathrm{Ni}$, or $\mathrm{Cr}$ using appropriate drift blanks. Quality control measures in analyzing the procedure were taken to confirm the accuracy of the analytical data. Samples were carefully handled to avoid contamination. Glasswares were cleaned properly. Deionized water was used throughout the study. Reagent blank determinations were used to correct the instrument readings during in the analyzes. About $25 \%$ of all samples were analyzed repeatedly to ensure the precision and accuracy of analysis. The detection limits for $\mathrm{Cd}$ and $\mathrm{Pb}$ were 0.33 and $1.01 \mathrm{mg} / \mathrm{kg}$, respectively. During the analyzes, the $\mathrm{Cd}$ and $\mathrm{Pb}$ detection limits reported as concentration of those elements in the sample when the elements $(\mathrm{Cd}$ and $\mathrm{Pb})$ were not determined due to their very low concentration. The other heavy metals concentrations were high in all samples and there was no problem with their detection limits. The mean, median, standard deviation, and range values were used to assess the contamination levels of heavy metals in soil (Excel 2007).

\section{Results and discussion}

\section{Soil characteristics}

The mean, maximum, minimum, standard deviation, $\mathrm{pH}$, electrical conductivity (EC), total organic material (TOM), and total organic carbon (TOC) values of soils in the study area and control site are given in Table 1. As indicated in Table 1, the $\mathrm{pH}$ of all soil samples was greater than 8.63 and the mean and maximum values were $9.29(\mathrm{SD} \pm 0.28)$ and 9.83 , respectively. It means the soil of the study area was alkaline. Alkaline soil $(\mathrm{pH}>8)$ can limit the mobilization of heavy metals in soil and can decrease their uptake by plants (Sharama et al. 2007). In comparison with the
Table 1 The mean, maximum, minimum, and standard deviation of $\mathrm{pH}$ and EC, TOM and TOC of soil samples

\begin{tabular}{lccll}
\hline & $\mathrm{pH}$ & \multicolumn{1}{l}{$\begin{array}{l}\mathrm{EC} \\
(\mu \mathrm{s} / \mathrm{cm})\end{array}$} & TOC (\%) & TOM (\%) \\
\hline Mean & 9.29 & 354.33 & 0.99 & 1.70 \\
Max & 9.83 & $1,100.00$ & 2.58 & 4.45 \\
Min & 8.63 & 120.00 & 0.09 & 0.17 \\
SD $( \pm)$ & 0.28 & 203.85 & 0.62 & 1.06 \\
Control site (plot no. 47$)$ & 8.82 & 48 & 0.99 & 1.71 \\
\hline
\end{tabular}

control soil $(\mathrm{pH}=8.82)$, the mean $\mathrm{pH}$ of the studied soil samples was higher. However, the $\mathrm{pH}$ and EC of soil may change due to the long-term application of chemical fertilizers (Zhen et al. 2009). According to documents from the agricultural department in the study area, a great deal of chemical fertilizer (sodium nitrates, ammonium sulphate, ammonium nitrate, ammonia, ammonium chloride and urea, diammonium phosphate, monoammonium phosphate, potassium nitrate, calcium nitrate, triple super phosphate, etc.) has been used in recent decades; therefore, the high $\mathrm{pH}$ was predictable. The mean, maximum, and minimum EC values of soil samples were determined to be 354.33 $( \pm 203.85) \mu \mathrm{s} / \mathrm{cm}, 1,100$ and $120 \mu \mathrm{s} / \mathrm{cm}$, respectively. The results indicated a mean, maximum, and minimum of $1.7 \%$ (SD \pm 1.06 ), $4.45 \%$ and $0.17 \%$ for TOM and $0.99 \%$ (SD \pm 0.62$), 2.58 \%$, and $0.09 \%$ for TOC, respectively. In comparison with the control soil, which had TOM and TOC values of $1.71 \%$ and $0.99 \%$, there was no significant difference. Total organic material includes all the elements (hydrogen, oxygen, nitrogen, etc.) that are components of organic compounds, not just carbon. The term organic material is different to TOC, which refers specifically to the organic carbon fraction. A conversion factor of 1.72 is used to convert organic carbon to organic matter. Total organic matter contains about $58 \%$ of organic carbon (Pluske et al. 2012). The result of this study with TOM/TOC of 1.717 and 0.582 was in agreement with the subject. Total organic material is sometimes incorrectly used to describe the same soil fraction as TOC. (Pluske et al. 2012). Organic matter plays a key role in soil physical, biological, and chemical properties, such as structural stability, porosity, nutrient availability, and ionexchange capacity (Bellanger et al. 2004; Mao et al. 2011).

Soils, as filters of toxic chemicals, may adsorb heavy metals. However, when the capacity of these soils is reduced because of the continuous entrance of pollutants or because of changes in $\mathrm{pH}$, heavy metals can be released into groundwater or soil solution available for plant uptake. The mobilization of heavy metals in the soil may depend on a number of factors, such as the $\mathrm{pH}$, clay content, organic matter content, and cation exchange capacity (Mapanda et al. 2005). With the exception of Mo, Se, and 
As, heavy metals mobility decreases as the soil $\mathrm{pH}$ increases due to the precipitation of hydroxides, carbonates, or the formation of insoluble organic complexes. Also, heavy metals are able to form insoluble complex compounds with soil organic matter (Mapanda et al. 2005).

Heavy metals contents in the soils

The soil sampling locations in the Tabriz city suburbs are shown in Fig. 1. The mean, maximum, minimum, and standard deviation of $\mathrm{Pb}, \mathrm{Cd}, \mathrm{Cu}, \mathrm{Zn}, \mathrm{Ni}$, and $\mathrm{Cr}$ and also the concentration of analyzed metals in the control soil are presented in Table 2 (Excel 2007). Also, the results of the present study were compared with the results of other studies conducted in different cities around the world and within Iran (Table 3). As indicted in Table 2, there was a wide range in the concentrations of heavy metals. The mean concentration of $\mathrm{Cd}$ was $1.61( \pm 1.52)$, and the maximum and minimum values were 5.33 and 0.33 (detection limit was $0.33 \mathrm{mg} / \mathrm{kg}$ ). The mean concentrations of $\mathrm{Cd}$ in the studied samples were higher than those in the control site $(1.17 \mathrm{mg} / \mathrm{kg})$, though the maximum concentration of $\mathrm{Cd}$ was much higher. The $\mathrm{Cd}$ concentration in suburban areas of Tabriz city was higher than the global mean concentration $(0.5 \mathrm{mg} / \mathrm{kg})$ and was also higher than values observed in other cities and in regions of other countries (Table 3) for example, Alicante (Spain), Trace (Turkey), Zagreb (Croatian), and Xuzhou (China) showed Cd concentrations of $0.3,0.2,0.66$, and $0.54 \mathrm{mg} / \mathrm{kg}$, respectively. Mapanda et al. (2005) carried out research in Harare, Zimbabwe in regions where wastewater was used for irrigation and reported a Cd concentration of $0.5-3.4 \mathrm{mg} / \mathrm{kg}$, which is very near to the values observed in the present study (Mapanda et al., 2005). From the results shown above, this study concluded that anthropogenic Cd pollution sources (metal smelting, sewage waters, the use of phosphate fertilizers, etc.) might currently be occurring in the study area or have been occurred in the past.

Table 2 The mean, maximum, minimum, and standard deviation of heavy metals $(\mathrm{Pb}, \mathrm{Cd}, \mathrm{Cu}, \mathrm{Zn}, \mathrm{Ni}$, and $\mathrm{Cr}$ ) in the soil samples $(\mathrm{mg} / \mathrm{kg}$ in dry weight) in comparison with control soil and toxicity threshold limit of agricultural soils

\begin{tabular}{lllllll}
\hline & $\mathrm{Cd}$ & $\mathrm{Pb}$ & $\mathrm{Cu}$ & $\mathrm{Cr}$ & $\mathrm{Ni}$ & $\mathrm{Zn}$ \\
\hline Mean & 1.61 & 10.56 & 101.25 & 87.40 & 38.73 & 98.27 \\
$\mathrm{Max}$ & 5.33 & 53.86 & 265.67 & $1,364.00$ & 72.50 & 163.80 \\
$\mathrm{Min}$ & 0.33 & 1.01 & 13.17 & 25.08 & 2.50 & 49.80 \\
$\mathrm{SD}( \pm)$ & 1.44 & 13.38 & 39.24 & 221.30 & 17.71 & 24.82 \\
$\begin{array}{l}\text { Plot no. 47 } \\
\quad(\text { control soil) }\end{array}$ & 1.17 & 3.05 & 69.00 & 38.31 & 47.50 & 69.80 \\
$\begin{array}{l}\text { TTLAS } \\
\quad \text { (Uosefian et al. }\end{array}$ & - & 1,500 & 400 & 1,500 & 2,000 & 5,000 \\
$\quad$ 2006) & & & & & & \\
\hline
\end{tabular}

${ }^{\text {a }}$ Toxicity threshold limit of agricultural soils
According to Table 2, the mean concentration of $\mathrm{Pb}$ in the suburbs of Tabriz city was $10.56( \pm 13.38)$, with minimum and maximum values of 1.01 (The detection limit was $1.01 \mathrm{mg} / \mathrm{kg}$ ) and $53.86 \mathrm{mg} / \mathrm{kg}$. In comparison with the control site $(\mathrm{Pb}$ concentration of $3.05 \mathrm{mg} / \mathrm{kg})$, the mean $\mathrm{Pb}$ in the study area was higher. However, the mean $\mathrm{Pb}$ value in the suburbs of Tabriz city was lower in comparison with that of other countries and cities (Table 3), such as Mexico (top soil, $140.5 \mathrm{mg} / \mathrm{kg}$ ), Bangkok (24.8 mg/kg), Hamburg $(32.5 \mathrm{mg} / \mathrm{kg})$, Madrid $(14.1 \mathrm{mg} / \mathrm{kg}$ ), and Isfahan (Iran, $75 \mathrm{mg} / \mathrm{kg})$, as well as with the global mean $(30 \mathrm{mg} / \mathrm{kg})$. The lower concentrations of $\mathrm{Pb}$ in the soil of the control site may indicate that there are some anthropogenic sources in the area, such as atmospheric perceptions and wastewater. The dominant winds in the city, which are from east and northeast toward west and southwest, respectively, probably played an important role in atmospheric perceptions in the area, especially in the past (Fig. 1). Most of the sites on the Tabriz suburban agricultural areas that are used for soil sampling are located in west and southwest. So the emissions transported by air from polluted atmosphere of city due to the huge car traffic are considered to be responsible for the increased $\mathrm{Pb}$ concentrations found in the soils. Of course, currently the using of $\mathrm{Pb}$ is banned in the gasoline.

As presented in Table 2, the mean concentration of $\mathrm{Cu}$ taken from 46 samples from the suburbs of the city was determined to be $101.25( \pm 39.24)$, and the maximum and minimum values were 265.67 and $13.17 \mathrm{mg} / \mathrm{kg}$, respectively. According to Table 2, the concentration of $\mathrm{Cu}$ in the control site in the area was determined to be $69 \mathrm{mg} / \mathrm{kg}$. Thus, the concentration of $\mathrm{Cu}$ in the study area was higher than that of the control site in the same area. Also, as indicted in Table 3, the comparison of the results of this study with other studies showed that the $\mathrm{Cu}$ concentration in the study area was higher than the concentrations of that element in other cities in Iran and in other countries except for Hamburg in Germany (Cu concentration of $146.6 \mathrm{mg} / \mathrm{kg}$ ). Due to the achieved concentration for $\mathrm{Cu}$, it can be assumed that the anthropogenic sources of pollution, such as industrial wastes and effluents, fertilizers, and sludge were already in the area or have been there in the past.

The $\mathrm{Cr}$ concentration in the soil of the study area is presented in Table 2, and compared with other cities in Iran as well as with other countries in Table 3. The mean concentration of $\mathrm{Cr}$ was $87.40 \mathrm{mg} / \mathrm{kg}( \pm 221.3 \mathrm{mg} / \mathrm{kg})$, and the maximum and minimum values were 1,364 and $25.08 \mathrm{mg} / \mathrm{kg}$, respectively.

The concentration of $\mathrm{Cr}$ in the control site was $38.31 \mathrm{mg} / \mathrm{kg}$. Again, a comparison of $\mathrm{Cr}$ concentration with that in other places [e.g., Mexico, $117 \mathrm{mg} / \mathrm{kg}$ (top soil); Bangkok, $26.4 \mathrm{mg} / \mathrm{kg}$; Hamburg, $95.4 \mathrm{mg} / \mathrm{kg}$; Madrid, $74.7 \mathrm{mg} / \mathrm{kg}$; Isfahan (Iran), $177 \mathrm{mg} / \mathrm{kg}$; Alicante (Spain), $27 \mathrm{mg} / \mathrm{kg}$ and Damascus (Syria), $57 \mathrm{mg} / \mathrm{kg}$ ] and 
Table 3 Average concentration of studied heavy metals $(\mathrm{mg} / \mathrm{kg})$ in soils of different cities in the world

\begin{tabular}{|c|c|c|c|c|c|c|}
\hline Places & $\mathrm{Cd}$ & $\mathrm{Pb}$ & $\mathrm{Cu}$ & $\mathrm{Cr}$ & $\mathrm{Ni}$ & $\mathrm{Zn}$ \\
\hline $\begin{array}{l}\text { Tabriz (present } \\
\text { study) }\end{array}$ & 1.69 & 10.86 & 101.25 & 87.40 & 38.73 & 98.27 \\
\hline $\begin{array}{l}\text { Mexico (Morton- } \\
\text { Bermea et al. } \\
\text { 2009) }\end{array}$ & - & 140.5 & 100.8 & 117 & 39.8 & 306.7 \\
\hline $\begin{array}{l}\text { Bangkok (Wilcke } \\
\text { et al. 1998) }\end{array}$ & - & 24.8 & 41.7 & 26.4 & 24.8 & 118 \\
\hline Hamburg (Lux 1986) & - & 62.5 & 146.6 & 95.4 & 62.5 & 516 \\
\hline $\begin{array}{l}\text { Madrid (De Miquel } \\
\text { et al. 1997) }\end{array}$ & - & 14.1 & 62.5 & 74.7 & 14.1 & 210 \\
\hline $\begin{array}{l}\text { Isfahan (Iran) } \\
\text { (Uosefian et al. } \\
\text { 2006) }\end{array}$ & - & 75 & 95 & 177 & 34 & 78 \\
\hline $\begin{array}{l}\text { Alicante (Spain) } \\
\text { (Mico et al. 2006) }\end{array}$ & 0.3 & 23 & 23 & 27 & 21 & 53 \\
\hline $\begin{array}{l}\text { Trace (Turkey) } \\
\text { (Sun et al. 2010) }\end{array}$ & 0.2 & 33 & 20 & - & - & 45 \\
\hline $\begin{array}{l}\text { Zagreb (Croatian) } \\
\text { (Sun et al. 2010) }\end{array}$ & 0.66 & 25.9 & 20.8 & - & - & 77.9 \\
\hline $\begin{array}{l}\text { Xuzhou (China) } \\
\text { (Sun et al. 2010) }\end{array}$ & 0.54 & 43.3 & 38.2 & - & - & 144.1 \\
\hline $\begin{array}{l}\text { Damascus (Syria) } \\
\text { (Moller et al. 2005) }\end{array}$ & - & 17 & 34 & 57 & 39 & 103 \\
\hline $\begin{array}{l}\text { World (mean) (Athar } \\
\text { and Vohora 1995) }\end{array}$ & 0.5 & 30 & 23 & 60 & 20 & 60 \\
\hline
\end{tabular}

with the global mean soil $\mathrm{Cr}$ concentration $(60 \mathrm{mg} / \mathrm{kg})$ indicted that the $\mathrm{Cr}$ concentration in the suburbs of Tabriz city was higher than that of the other cities and places except for Mexico, Hamburg, and Isfahan (Iran). There were two sites (points 23 and 26 at N 3804 55.2-E 04611 44.7 and N $380427.3-\mathrm{E} 0461124.2$ in Fig. 1) that showed very high pollution values of $\mathrm{Cr}$, with concentrations of 780.5 and $1,364 \mathrm{mg} / \mathrm{kg}$, respectively. The wastewater and sludge from the tanning, electroplating industry, in the area was likely a major source of $\mathrm{Cr}$ entering into the soil in the western suburbs of the city.

A survey of concentrations of $\mathrm{Ni}$ in the area indicted that the mean Ni concentration was $38.73( \pm 17.71) \mathrm{mg} / \mathrm{kg}$ with a range of $2.50-72.50 \mathrm{mg} / \mathrm{kg}$. As presented in Table 3, the following Ni concentrations were reported for different countries: Mexico, $39.8 \mathrm{mg} / \mathrm{kg}$ (top soil); Bangkok, $24.8 \mathrm{mg} / \mathrm{kg}$; Hamburg, $62.5 \mathrm{mg} / \mathrm{kg}$; Madrid, $14.1 \mathrm{mg} / \mathrm{kg}$; Isfahan (Iran), $34 \mathrm{mg} / \mathrm{kg}$; Alicante (Spain), $21 \mathrm{mg} / \mathrm{kg}$ and Damascus (Syria), $39 \mathrm{mg} / \mathrm{kg}$, with a global mean value of $20 \mathrm{mg} / \mathrm{kg}$. With the exception of Hamburg in Germany, the $\mathrm{Ni}$ concentration in this study was equal to or greater than that of Iran and other countries. As shown in Table 2, the $\mathrm{Ni}$ concentration was higher in the control site than the mean from the other 46 samples taken. That indicates the control site has been polluted accidentally due to unknown reasons in the past time or the background concentration of $\mathrm{Ni}$ in that site naturally was higher. Understanding the exact reason might need more study in that site.

The mean, maximum, and minimum concentrations of $\mathrm{Zn}$ were determined to be $98.27( \pm 24.82), 163.80$, and $49.8 \mathrm{mg} / \mathrm{kg}$, respectively. In some cases, the $\mathrm{Zn}$ concentration in this study (Table 3) was lower and in other cases, higher than in other cities and places (Mexico, $306.7 \mathrm{mg} / \mathrm{kg}$ (top soil); Bangkok, $118 \mathrm{mg} / \mathrm{kg}$; Hamburg, $516 \mathrm{mg} / \mathrm{kg}$; Madrid, $210 \mathrm{mg} / \mathrm{kg}$; Isfahan (Iran), $78 \mathrm{mg} / \mathrm{kg}$; Alicante (Spain), $53 \mathrm{mg} / \mathrm{kg}$; Trace (Turkey) $45 \mathrm{mg} / \mathrm{kg}$; Zagreb (Croatian) $77.9 \mathrm{mg} / \mathrm{kg}$; Xuzhou (China) $141.1 \mathrm{mg} / \mathrm{kg}$ and Damascus (Syria), $103 \mathrm{mg} / \mathrm{kg}$, with a global mean value of $60 \mathrm{mg} / \mathrm{kg}$ ). In addition, $\mathrm{Zn}$ values were higher than the control site, with a value of $69.80 \mathrm{mg} / \mathrm{kg}$ and a global mean concentration of $60 \mathrm{mg} / \mathrm{kg}$. Fertilizers, sewage sludge, and atmospheric industrial dust can be considered to be an anthropogenic source of $\mathrm{Zn}$ accumulation in soils.

Soil pollution indices

Many indices and calculation methods, such as geoaccumulation index (Igeo), pollution index (PI), and integrated pollution index (IPI) have been proposed for quantifying the degree of metal enrichment or pollution in soils, sediments (Faiz et al. 2009; Chen et al. 2005; Sun et al. 2010; Wei and Yang 2011; Lu et al. 2009; Abanuz 2011).

The PI and IPI are commonly used to assess environmental quality (Lu et al. 2009). In general, the PI was defined as the ratio of the heavy metals concentration in environment to the geometric means of the natural background concentration of the corresponding metal (Chen et al. 2005; Sun et al. 2010; Wei and Yang 2011). PI was calculated as:

$\mathrm{PI}=\frac{C_{\mathrm{i}}}{S_{\mathrm{i}}}$

where PI is the evaluation score corresponding to each sample, $C_{\mathrm{i}}$ is the measured concentration of the examined metals in the soils, and $S_{\mathrm{i}}$ is the geochemical background concentration of the metals (in this study due to the unavailability of geometric background concentration of studied area the geometric mean concentrations of control site was taken as natural background concentration). The PI value of each metal was calculated and classified as either having a low contamination ( $\mathrm{PI} \leq 1.0$ ), a moderate contamination $(1.0<\mathrm{PI} \leq 3.0)$ or a high contamination (PI > 3.0) (Chen et al. 2005, Lu et al. 2009). IPI was defined as the mean values for all PI values of all of the considered metals and then classified as having a low contamination (IPI $\leq 1.0)$, a moderate contamination $(1.0<$ IPI $\leq 2.0)$ or a high contamination $(2<$ IPI $\leq 5)$, and extremely high level of contamination (IPI $>5$ ) (Chen et al. 2005; Lu et al. 2009; Sun et al. 2010; Wei and Yang 2011; Abanuz 2011). 
The PI and IPI values for all of the heavy metals in the study area are presented in Table 4 . The PI was different across the surveyed heavy metals. For $\mathrm{Cd}$, the PI values varied from 0.28 to $4.56 \mathrm{mg} / \mathrm{kg}$ with a mean value of $1.45 \mathrm{mg} / \mathrm{kg}(1.0 \mathrm{mg} / \mathrm{kg}<\mathrm{PI} \leq 3.0 \mathrm{mg} / \mathrm{kg}$ was considered to be moderate pollution). A total of $17.39 \%$ ( 8 samples) and $21.73 \%$ (10 samples) of analyzed soil samples had moderate and high pollution values, respectively. The mean $\mathrm{PI}$ for $\mathrm{Pb}$ was determined to be $3.56 \mathrm{mg} / \mathrm{kg}$ ( $>3$ high pollution) with a range of $0.33-17.66 \mathrm{mg} / \mathrm{kg}$. According to Table 4, 15.21 and $39.13 \%$ of $\mathrm{Pb}$ samples, respectively, had moderate and high pollution conditions. The $\mathrm{Cu}$ and $\mathrm{Cr}$ values of PI were determined to be 1.47 and 2.28 , indicating moderate pollution levels for both of these substances. For $\mathrm{Cu}, 89.13 \%$ of samples showed moderate pollution levels and $2.17 \%$ showed high pollution levels, while for $\mathrm{Cr}, 56.52 \%$ showed moderate pollution levels, $4.34 \%$ showed high pollution levels, and the remaining samples showed low pollution conditions. Ni values were better in terms of pollution index because the mean value of PI for Ni was determined to be 0.82 (PI $\leq 1.0$ ), indicating low pollution in the area regarding this element. Of the 46 samples, $76.09 \%$ showed low levels of $\mathrm{Ni}, 23.91 \%$ showed moderate $\mathrm{Ni}$ levels, and $0 \%$ showed high $\mathrm{Ni}$ pollution levels. Finally, for $\mathrm{Zn}$, the mean value of PI was 1.41 and moderate pollution was observed throughout most of the study area. In total, $10.87 \%$ (5 samples), $89.13 \%$ (41 samples), and $0 \%$ (0 samples) showed low, moderate, and high pollution levels, respectively.

The mean value of the IPI was determined to be $1.83 \mathrm{mg} / \mathrm{kg}$ $(1.0 \mathrm{mg} / \mathrm{kg}<\mathrm{IPI} \leq 2.0 \mathrm{mg} / \mathrm{kg})$ with a range of $0.05-35.36$ $\mathrm{mg} / \mathrm{kg}$, indicating a moderate pollution condition. There were $111(40.22 \%)$ samples with an IPI value less than 1.0 (low contamination), 121 (43.84\%) samples with IPI values between 1.0 and 2.0 (moderate contamination), 32 (11.59\%) samples with IPI values $(2<$ IPI $\leq 5)$ (high contamination), and 12 (4.35\%) samples with IPI values greater than 5 (extremely high contamination). In terms of the IPI criteria, the study area was found to be moderately to highly polluted with heavy metals. In comparison with IPI $<1.0$ of Beijing city (china) (Wei and Yang, 2011) the studied area was more contaminated. But in comparison with five other heavy industrial cities of China (Changchun, Shenyang, Changsha, Baoji and Jinchang) with IPI $>$ 5.0, had better condition (Wei and Yang, 2011). However, the results indicated that the soils around of Tabriz city may be significantly influenced by traffic sources and industrial sources such as smelting, power plants, metallurgical industry, tanning and electroplating industry chemical plant, auto repair shop, waste disposal, urban effluent, vehicle exhausts, sewage sludge, pesticides, and fertilizers application, etc.

\section{Conclusion}

The soil of the study area was alkaline, and the organic material content (TOC and TOM) showed almost the same conditions in comparison with other study results. With the exception of $\mathrm{Ni}$, the average concentrations of the studied heavy metals $(\mathrm{Cd}, \mathrm{Pb}, \mathrm{Cu}, \mathrm{Cr}$, and $\mathrm{Zn}$ ) were greater than those in the control soil (No 47). In addition, the average concentrations of the studied heavy metals, with the exception of $\mathrm{Pb}$, were greater than the global average concentrations. However, most of the concentrations of studied heavy metals were lower than the toxicity threshold limit of agricultural soils. Of course, there were some farms that were severely polluted with chromium. Currently, the IPI showed a moderate level of pollution in the area. Due to a lack of past data regarding the concentrations of heavy metals in the area, it was not possible to determine the trend of changes. However, the concentrations of heavy metals are likely to be increasing in the area because of the increase in anthropogenic sources and rapid urbanization. The use of wastewater (municipal and industrial) as irrigation water and sludge as fertilizer in farms and using of sludge as soil fertilizer and atmospheric perceptions have been considered as main reasons for increased heavy metals concentrations found in the studied area.

According to the condition of region, several factors, including the following, can be proposed to improve management and decrease the source of pollutants: educating the farmers; more control and monitoring for the non-application of wastewater as irrigation water and sludge as fertilizer

Table 4 Pollution index (PI) and integrated pollution index (IPI) of heavy metals in suburb soil of Tabriz city

\begin{tabular}{|c|c|c|c|c|c|c|c|c|c|c|c|c|c|}
\hline \multirow[t]{2}{*}{ Heavy metals } & \multicolumn{3}{|l|}{ PI } & \multicolumn{3}{|c|}{ Number of samples } & \multicolumn{3}{|l|}{ IPI } & \multicolumn{4}{|c|}{ Number of samples } \\
\hline & Mean & Max & Min & Low & Moderate & High & Mean & Max & Min & Low & Moderate & High & Extremely high \\
\hline $\mathrm{Cd}$ & 1.45 & 4.56 & 0.28 & 28 & 8 & 10 & 1.83 & 35.60 & 0.05 & 111 & 121 & 32 & 12 \\
\hline $\mathrm{Pb}$ & 3.56 & 17.66 & 0.33 & 21 & 7 & 18 & & & & & & & \\
\hline $\mathrm{Cu}$ & 1.47 & 3.85 & 0.19 & 4 & 41 & 1 & & & & & & & \\
\hline $\mathrm{Cr}$ & 2.28 & 35.6 & 0.65 & 18 & 26 & 2 & & & & & & & \\
\hline $\mathrm{Ni}$ & 0.82 & 1.53 & 0.05 & 35 & 11 & 0 & & & & & & & \\
\hline $\mathrm{Zn}$ & 1.41 & 2.35 & 0.71 & 5 & 41 & 0 & & & & & & & \\
\hline
\end{tabular}


in farms; and accelerating the completion of industrial and municipal wastewater collection and treatment systems.

Future research should be conducted using the same conditions to determine the trend of heavy metals concentrations and their accumulation in the soil. Due to other likely pollution source of heavy metals, such as agricultural fertilizers, pesticides, fungicides, etc., there should be more control over and research on these sources.

Acknowledgments This study was funded by the research deputy, National Public Health Management Center (NPMC) and the Nutrition Research Center of the Tabriz University of Medical Science. The authors wish to thank all of the members of the survey team who participated in the study.

\section{References}

Alexandera PD, Allowayb BJ, Douradoa AM (2006) Genotypic variations in the accumulation of $\mathrm{Cd}, \mathrm{Cu}, \mathrm{Pb}$ and $\mathrm{Zn}$ exhibited by six commonly grown vegetables. Environ Pollut 144(3):736-745

Asgharszadeh NA, Saleh Rastin N, Towfighi H, Alizadeh A (2001) Occurrence of Arbuscular Mycrrhizal Fungi in saline soils of Tabriz plain in relation to some physical and chemical properties of soil. Iranian J Agric Sci 32(1):89-99 (Persian)

APHA (2006) Standard method for the examination of water and wastewater, 18th. American Public Health Association, Washington DC

Athar M, Vohora SB (1995) Heavy metals and environment. New age international limited publication. ISBN 978-81-224-0769-3

Abanuz GY (2011) Heavy metal contamination of surface soil around Gebze industrial area. Turk Microchem J 99:82-92

Bellanger B, Huon S, Velasquez F, Valle's V, Girardin C, Mariotti A (2004) Monitoring soil organic carbon erosion with $\partial 13 \mathrm{C}$ and a15 $\mathrm{N}$ on experimental field plots in the Venezuelan Andes. Catena 58:125-150

Chen TB, Zheng YM, Lei M, Huang ZC, Wu HT, Chen H, Fan KK, Yu K, Wu X, Tian QZ (2005) Assessment of heavy metal pollution in surface soils of urban parks in Beijing, China. Chemosphere 60:542-551

De Miguel E, Llamas JF, Chacon E, Berg T, Larssen S, Royset O, Vadset M (1997) Origin and patterns of distribution of trace elements in street dust: unleaded petrol and urban lead. Atmospheric Environ 31:2733-2740

European Union (2002) Heavy Metals in Wastes, European Commission on Environment. http://ec.europa.eu/environment/ waste/studies/pdf/heavymetalsreport.pdf

Faiz Y, Tufail M, Tayyeb Javed M, Chaudhry MM, Siddique N (2009) Road dust pollution of $\mathrm{Cd}, \mathrm{Cu}, \mathrm{Ni}, \mathrm{Pb}$ and $\mathrm{Zn}$ along Islamabad Expressway, Pakistan. Microchem J 92:186-192

Huang B, Shi X, Yu D, Ingrid O born I, Blomback K, Pagella TF, Wang H, Sun W, Sinclair FL (2006) Environmental assessment of small-scale vegetable farming systems in peri-urban areas of the Yangtze River Delta Region. China. Agric Ecosyst Environ 112:391-402

Kaushik A, Kansal A, Meena S, Kumari S, Kaushik CP (2009) Heavy metal contamination of river Yamuna, Haryana, India: Assessment by Metal Enrichment Factor of the Sediments. J Hazard Mater 164:265-270

Koshhal Dastgerdy J, Gavidel R (2009) Survey of relationship between annual raining of Tabriz and climate changes by simulation of artificial neural network. Modares J Manag 12(2):29-51 (Persian)
Kasassi A, Rakimbei P, Karagiannidis A, Zabaniotou A, Tsiouvaras K, Nastis A, Tzafeiropoulou K (2008) Soil contamination by heavy metals: measurements from a closed unlined landfill. Bioresour Technol 99:8578-8584

Lu X, Wang 1, Lei K, Huang J, Zhai Y (2009) Contamination assessment of copper, lead, zinc, manganese and nickel in street dust of Baoji, NW China. J Hazard Mater 161:1058-1062

Lux W (1986) Shhwermetallgehalte und isoplethen in Boden, subhydrishen Ablagerung und Pflanzen im Sudosten Hamburgs. Hamburger Bodenkudliche Arbeiten 5, 249

Moller A, Muller HW, Abdullah A, Abdelgawad G, Utermann J (2005) Urban soil pollution in Damascus, Syria: concentrations and patterns of heavy metals in the soils of the Damascus Ghouta. Geoderma 124:63-71

Mapanda F, Mangwayana EN, Nyamangara J, Giller KE (2005) The effect of long-term irrigation using wastewater on heavy metal contents of soils under vegetables in Harare, Zimbabwe. Agric Ecosyst Environ 107(2-3):151-165

Mico C, Ŕecatala L, 'Peris M, Sańchez J (2006) Assessing heavy metal sources in agricultural soils of an European Mediterranean area by multivariate analysis. Chemosphere 65:863-872

Morton-Bermea O, Hernández-Álvarez E, González-Hernández G, Romero F, Lozano R, Beramendi-Orosco LE (2009) Assessment of heavy metal pollution in urban top soils from the metropolitan area of Mexico City. J Geochem Explo 101:218-224

Mao R, Zeng DH, Li LJ, Hu YL (2011) Changes in labile soil organic matter fractions following land use change from monocropping to poplar-based agroforestry systems in a semiarid region of Northeast China. Environ Monit Assess. doi:10.1007/s10661011-2462-3

Page AL, Miller RH, Keeney DR (1982) Methods of soil analysis, Part 2, 2nd. Agronomic monograph, vol 9. American Society of Agronomy and Soil Science Society of America, Madison, WI

Pluske W, Murphy D, Sheppard J (2012) Soil organic matter. http:// www.agric.gov.ab.ca/department/deptdocs.nsf/all/aesa1861/file/ organicmatter.pdfOpen\%20Elemen. Accessed in May 2012

Qadir M, Wichelns D, Raschid-Sally L, McCornick PG, Drechsel P, Bahri A, Minhas PS (2010) The challenges of wastewater irrigation in developing countries. Agric Water Manag 97:561-568

Radwan MA, Salama Ak (2006) Market basket survey for some heavy metals in Egyptian fruits and vegetables. Food Chem Toxicol 44:1273-1278

Singh A, Sharma RK, Agrawal M, Marshall FM (2010) Health risk assessment of heavy metals via dietary intake of foodstuffs from the wastewater irrigated site of a dry tropical area of India. Food Chem Toxicol 48:611-619

Sharma RK, Agrawal M, Marshall F (2007) Heavy metal contamination of soil and vegetables in suburban areas of Varanasi, India. Ecotoxicol Environ Safety 66(2):258-266

Sun Y, Zhou Q, Xie X, Liu R (2010) Spatial, Source and risk assessment of heavy metal contamination of urban soils in typical regions of Shenyang. China. J Hazard Mater 174:455-462

Uosefian A, Pourmogads H, Vahid Dastjerdi M (2006) Survey of heavy metals concentrations in water, soil, and irrigated plants with water extracted from Bama Lead mine. 8th Ir. Nation Environ cong (Persian)

Wilcke W, Muller S, Kanchanakool N, Zech W (1998) Urban soil contamination in Bangkok: heavy metal and aluminum partitioning in tops oils. Geoderma 86:211-228

Wei B, Yang L (2011) A review of heavy metal contaminations in urban soils, urban road dusts and agricultural soils from China. Microchem J 94:99-107

Zhen HX, Mei ZD, Qian HD, Long C, Lin ZH, Wang Hui W (2009) Heavy Metal Transfer from Soil to Vegetable in Southern Jiangsu Province. China. Pedosphere 19(3):305-311 